\title{
JIŘÍ LEVÝ A ČESKÁ ANGLISTIKA A AMERIKANISTIKA
}

\author{
BOHUSLAV MÁNEK
}

\begin{abstract}
The Czech literary scholar Jiří Levý (1926-1967) has gained international recognition for his great contribution to the general theory of translation and has greatly contributed to the history and theory of translation into the Czech language in his books Umèní prekladu (1963; Die literarische Übersetzung: Theorie einer Kunstgattung, German transl., 1969; The Art of Translation, English transl., 2011) and České theorie prekladu (1957, Czech Theories of Translation), respectively. His other distinguished research included versology, theatrology and various studies on British and American writers. This paper focuses on two related but less discussed aspects of his oeuvre - his contribution to Czech Anglophone Studies and his early translations of foreign poetry into Czech. It chronologically surveys Levýs papers in the field of Anglophone Studies and outlines their contribution to Levýs translatological oeuvre. It also includes their bibliography and a hitherto unpublished tentative bibliography of his Czech translations of poetry with two specimens of his translations.
\end{abstract}

Key words: Jiří Levýs papers on British and American literature, Czech British and American Studies, Jiř́ Levýs early translations of foreign poetry into Czech

U př́ležitosti padesátého výročí předčasné smrti Jiř́ho Levého v lednu 1967 jak čeští, tak i zahraniční translatologové a literární vědci publikovali množství studií, a to především o jeho př́nosu české a světové translatologii. Levého badatelský zájem zahrnoval také versologii, teatrologii, dějiny a teorii literatury, do nichž vnášel i některé metody exaktních věd. Záměrem této práce je upozornit na dva další, vzájemně a také s translatologií související aspekty jeho díla - jeho přínos české anglistice a jeho rané časopisecké překlady světové poezie do češtiny.

Již od doby studií byl Levý velmi pilný recenzent především v Časopise pro moderní filologii, což mu poskytovalo široký přehled o vývoji soudobé literární vědy. Své znalosti později zúročil jako editor antologie Západní literární věda a estetika (1966), pro niž i některé studie přeložil a zpracoval rozsáhlou bibliografii. Charakteristickým rysem jeho bádání jako celku je, že se nejedná o paralelní nebo divergentní linie, nýbrž o syntézu, manifestovanou především v jeho stěžejním díle, Umění překladu (1963). 
Na význam Levého anglistických studií upozornil již v „Bibliografické poznámce“ k souboru Bude literární věda exaktní vědou? jeho editor Miroslav Červenka tím, že kromě vybraných několika dílčích prací a zcela zásadních syntetizujících translatologických, teatrologických, versologických a literárněvědných studií zařadil i nejvýznamnější „práce o anglické literatuře, širší veřejnosti dosud poměrně málo známé.“ (Červenka 1971: 457) Některé práce původně publikované anglicky v zahraničí byly pro uvedený výbor přeloženy do češtiny (Levý 1952, 1959).

Levého práce o britské a americké literatuře se ubíraly několika směry. Nejprve koncem čtyřicátých let publikoval řadu studií o různých aspektech poezie T. S. Eliota (způsob myšlení, struktura a veršová technika), vycházejících z kvalifikačních prací, jimiž ukončil studia anglistiky a bohemistiky na Masarykově univerzitě v Brně roku 1949, z diplomové práce The Poetry of T. S. Eliot, Its Unity and Development (Poezie T. S. Eliota, její jednota a vývoj) a z PhDr. dizertace Srovnávací pohled na anglický verš (viz chronologicky usporádanou Bibliografii vybraných hlavních anglistických a amerikanistických prací Jiř́ho Levého níže).

Další směr bádání představují jeho práce o anglické renesanci. Od poloviny padesátých let publikoval studie o dramatech Bena Jonsona a Williama Shakespeara „Ben Jonson - jeho doba a dílo“ a „William Shakespeare a Ben Jonson - dva typy dramatu“ (1956), „Divadelní prostor a čas v dramatech Williama Shakespeara a Bena Jonsona“ (1958), které mu poskytly rovněž podklady pro pozdější rozsáhlou translatologickou studii „O překládání shakespearovského verše a prózy“ (1964) v aparátu kritického vydání Shakespearových děl v překladech Sládka, Klášterského a Vrchlického editovanou Otakarem Vočadlem (Shakespeare 1959-64). Jeho průkopnickým př́spěvkem v této oblasti jsou dvě rozsáhlé studie „The Development of Rhyme-Scheme and of Syntactic Pattern in the English Renaissance Sonnet“ (Vývoj rýmového schématu a syntaktických vzorců v anglickém renesančním sonetu) a „On the Relations of Language and Stanza Pattern in the English Sonnet“ (O vztahu jazyka a struktury strofy v anglickém sonetu, obě 1961). V těchto studiích Levý podal detailní analýzy vybraných renesančních a dalších sonetů jak z hlediska rozvíjení myšlenek v nich, tak i vývoje jejich formální struktury, od raných verzí překladů Petrarkových sonetů od Wyatta a Surreyho k sonetům Watsona, Daniela, Sidneyho, Spensera, Shakespeara, některých méně známých alžbětinských básníků, Miltona ke Keatsovi, D. G. Rossettimu, Barrett-Browningové a G. M. Hopkinsovi. Obě studie především analyzují způsob, jakým konstitutivní prvky jazyků působí na veršové formy. Levý zde dále rozvinul metodologii ruských formalistů a českých strukturalistů, v té době marxisticky orientovanou kritikou odmítaných - dovolil si citovat např. S. I. Karcevského, B. V. Tomaševského a Travaux du cercle linguistique de Prague. Na základě těchto rozborů rozsáhlých materiálů Levý došel k závěrům o složitých interakcích struktury jazyků, rýmových schémat, syntaktických vzorců a myšlenek ve vývoji sonetu. Své poznatky později spojil s dalšími svými versologickými studiemi a využil je v kapitolách o rytmu a rýmu v knize Umění prekladu (1963: 178-226), kde formuloval důležité závěry dovolující spojit analýzy textů s historickým vývojem: „Rozdíl rýmových možností anglických a italských byl asi hlavní příčinou, proč petrarkovský sonet o schématu $a b b a$ abba $c d c c d c$ zdomácněl v anglické literatuře ve zjednodušené shakespearovské podobě $a b a b c d c d$ efefgg." 
Soubornou edici by si také zasloužily Levého kvalitní popularizační předmluvy a doslovy k českým překladům básní Yeatse (1961) a Blakea (1964), Gayovy Žebrácké opery a Polly (1964), Wildeova románu Obraz Doriana Graye (1964) a Shakespearova dramatu Romeo a Julie (1964). Dušan Jeřábek (1967: 169) v Levého nekrologu zdůraznil význam Levého anglistických prací pro český kulturní kontext: Levý vybíral autory, kteři bud' již měli své vlivné místo v české recepci, a pak autory, které považoval za v českém kontextu podhodnocené. Levého práce o anglické literatuře sledovaly rovněž komparatistické hledisko, např́klad ve studii „Čapkův Loupežník a Shakespeare“ (1956) o shakespearovských motivech v Čapkově divadelní hře Loupežník (přetištěno rovněž v souboru Bude literární věda exaktní vědou?, 1971). Komparatistický zřetel k češtině a české literatuře prochází prakticky celým Uměním překladu (1963). Podobně ve studii „Československý strukturalismus a zahraniční kontext“ (Levý 1966) podal porovnání vývoje metodologie cambridgeské školy a „nové kritiky“ a českého strukturalismu v historických souvislostech.

$\mathrm{O}$ americké literatuře Levý publikoval pouze několik studií - $\mathrm{k}$ některým tématům a k některým autorům se vyjádřil většinou v rámci translatologických studií o překladech jejich děl do češtiny. Nicméně jeho první publikovaná práce byl rozsáhlý rozbor literárních esejů o americké a světové literatuře „Kritické názory D. H. Lawrence“ (1946-1947), kde analyzoval jeho knihy Studies in Classic American Literature (1923, Studie o klasické americké literatuře) and Phoenix (1936, Fénix) a charakterizoval jejich autora a jeho pojetí literatury. Jeho hlavní amerikanistické př́spěvky se věnovaly Waltu Whitmanovi a vznikly v souvislosti s oslavami stého výročí vydání Stébel trávy roku 1955.

Dobové nekrology a životopisná hesla v encyklopediích (např. Macura 1999) se zmiňují o jeho raných překladech poezie publikovaných v deníku Svobodné noviny a v časopise Kvart. Tyto překlady by mohly vrhnout světlo na vztah jeho raných osobních překladatelských zkušeností $\mathrm{k}$ jeho pozdějšímu teoretickému myšlení a zasloužily by si proto podrobnějši samostatné zkoumání. Nicméně jsme nebyli schopni najít žádnou bibliografii jeho překladů poezie a ani badatelé dotázaní na symposiu k úmrtí Jiř́ho Levého konaném na Ústavu translatologie Filozofické fakulty University Karlovy v Praze v lednu 2017 o takové bibliografii také nevěděli. Proto jsme podnikli vlastní rešerši a zpracovali níže uvedenou Bibliografii dosud zjištěných překladů poezie Jiř́ho Levého, obsahující zatím zjištěných dvanáct básní od jedenácti básníků (sedm piśících anglicky, dva španělsky, jeden francouzsky a jeden arabský anonym, zřejmě přeložený z některého ze světových jazyků). ${ }^{1}$ Pro ilustraci zde zařazujeme dvě ukázky Levého překladů, kratší básně Williama Butlera Yeatse a Hugh MacDiarmida:

\section{Down by the Salley Gardens \\ Down by the salley gardens my love and I did meet; \\ She passed the salley gardens with little snow-white feet. \\ She bid me take love easy, as the leaves grow on the tree; \\ But I, being young and foolish, with her would not agree.}

1 Svobodné noviny $\mathrm{v}$ tomto období otiskly rovněž několik překladů $\mathrm{z}$ francouzštiny podepsané Igor Levý, např. texty od Ivana Golla a Valéry Larbauda, č. 229, 1. 10. 1947, s. 1, č. 22, 27. 1. 1948, s. 1. Autorovi tohoto článku se nepodařilo zjistit identitu překladatele, ani zda se jedná o pseudonym či opakovanou chybu tisku. Protože ostatní překlady jsou podepsány Jiří Levý, do Bibliografie překladů byly tedy zařazeny pouze správně podepsané překlady. Tento problém si zaslouží další podrobnější zkoumání. 
In a field by the river my love and I did stand,

And on my leaning shoulder she laid her snow-white hand.

She bid me take life easy, as the grass grows on the weirs;

But I was young and foolish, and now am full of tears. ${ }^{2}$

\section{U zahrad na stráni}

U zahrad na stráni jsem potkal lásku svou.

Kol zahrad na stráni šla nožkou bělostnou

a radila, bych lásku lehce nes

jak listí na stromech;

však já jsem mladý blázen byl

a jí jsem neposlech.

U řeky v polích stál jsem s láskou svou.

Na skleslé rámě vložila mi ruku bělostnou

a radila, bych život lehce nes

jak trávu podle lomu;

však já jsem mladý blázen byl

a proto $\mathrm{v}$ slzách tonu. ${ }^{3}$

Později v rámci svého informativního článku „Skotský regionalismus v poválečné britské literatuře" v Časopise pro moderní filologii (Levý 1951: 151-155) přeložil z formující se literární skotštiny báseň ilustrující jeho vnímavost, vysoké nároky na překlad a sebekritičnost: „Hugh MacDiarmid [...] propracovává novou skotskou básnickou řeč do překvapující náladové a zvukové expresivity. Postačí, ocitujeme-li jazykově obtížnou, ale krásnou báseň ,The Watergaw‘ i s volným českým překladem, který ovšem zdaleka nemůže reprodukovat vpravdě duhovou hláskovou hudbu originálu[.]“

\section{The Watergaw}

Ae weet forenicht i' the yow-trummle

I saw yon antrin thing,

A watergaw wi' its chitterin' licht

Ayont the on-ding;

An' I thocht o' the last wild look ye gied

Afore ye deed!

There was nae reek i' the laverock's hoose

That nicht-an' nane i' mine:

But I ha'e thocht o that foolish licht

Ever sin' syne;

An' I think that mebbe at last I ken

What your look meant then. ${ }^{4}$

2 Salley (willow - vrba) in Yeats-Larissy (2001: 11).

3 Svobodné noviny 3, 1947, č. 118, 21. května, s. 1. Jiný existující český překlad je „Pod jívovými sady“ in William Butler Yeats (1961) Slova snad pro hudbu. Přel. Jiří Valja. Praha: SNKLU, 25.

4 MacDiarmid, Hugh and Michael Grieve, Alexander Scott (eds.) (1977) Hugh MacDiarmid Anthology, London: Routledge and Kegan Paul, 3. Výrazy ze skotštiny: watergaw (indistinct rainbow - nezřetelná mlha), weet (wet - vlhký), forenicht (early evening - podvečer), yow-trummle (cold weather after 


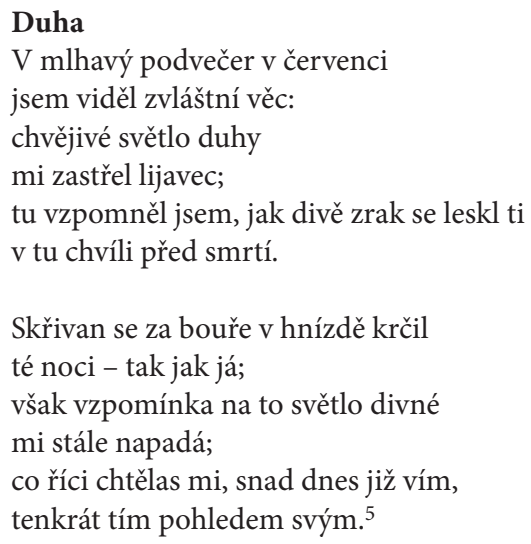

Máme-li celkově postihnout Levého prŕnos české anglistice a amerikanistice a literární vědě, lze připomenout zmíněný nekrolog Miroslava Červenky (1967: 162), který zhodnotil Levého literárněvědnou metodologii následovně: „Analytické práce o Whitmanovi a T. S. Eliotovi se těsně přibližují Mukařovského rozborům sémantického gesta[.] "6 Rovněž na základě Levého ostatních anglistických prací lze říci, že Levý navázal na strukturalismus Pražského lingvistického kroužku v období, kdy z politických a dalších příčin byl potlačován, a že i v těžkých dobách byl schopen udržet kontakt $\mathrm{s}$ vývojem světové literární vědy ku prospěchu české anglistiky, bohemistiky a samozřejmě rozvíjející se translatologie.

\section{BIBLIOGRAFIE VYBRANÝCH HLAVNÍCH ANGLISTICKÝCH A AMERIKANISTICKÝCH PRACÍ JIŘíHO LEVÉHO7}

Levý, Jiří (1946-1947) 'Kritické názory D. H. Lawrence’, Časopis pro moderní filologii 30 (3): 202-216.

_- (1948-1949) 'Ideový základ tvưrčí metody T. S. Eliota', Časopis pro moderní filologii 32 (3): 139142.

(1949a) The Poetry of T. S. Eliot, Its Unity and Development, Diplomová práce, Masarykova universita, Brno. Strojopis.

(1949b) Srovnávací pohled na anglický verš, PhDr. disertace, Masarykova Universita, Brno. Strojopis.

(1950-1951) 'Skotský regionalismus v poválečné britské literatuře', Časopis pro moderní filologii 34 (4): 151-155.

sheep-shearing - chladné počasí po období stř́hání ovcí), antrim (rare - vzácný), chitterin’ (shivering - chvějící se), licht (light - světlo), ayont (behind - za), on-ding (onset of rain - nástup deště), thocht (thought - myslel), gied (gave - dal), deed (died - zemřel), nae (no - ne), reek (smoke - kouř), laverock (lark - skřivan), hoose (house - dủm), nicht (night - noc), nane (none - žádný), ha’e thocht (have thought - myslel), sin' syne (since then - od té doby), mebbe (may be - možná), ken (know vědět).

5 Časopis pro moderní filologii 34, 1951 (4): 153-54.

6 Červenka 1967: 162.

7 Zde jsou uvedeny práce, které autor této bibliografie hodnotí jako nejdůležitější př́nos Jiř́ho Levého české anglistice a amerikanistice. Celkové bibliografie Levého odborných prací uvádí Theimerová 1967 a www.phil.muni.cz/angl/levy/levy_bibtheimer.rtf. 
(1952) 'Synthesis of Antitheses in the Poetry of T. S. Eliot', Essays in Criticism 2(4): 434-443.

(1955a) 'K podstatě básnické metody Walta Whitmana', Sborník Vysoké školy pedagogické v Olomouci. Jazyk a literatura (2): 127-158.

(1955b) 'K jubileu Walta Whitmana', Host do domu 2(6): 263-265.

(1955c) 'Walt Whitman v českých překladech', Host do domu 2(11): 513-515.

(1956a) ‘Čapkův Loupežník a Shakespeare’, Sborník Vysoké školy pedagogické v Olomouci. Jazyk a literatura (3): 141-145.

(1956b) 'Ben Jonson - jeho doba a dílo. Ben Jonson a William Shakespeare - dva typy dramatu', in Ben Jonson, Alchymista, Praha: Orbis, 5-53.

(1957) 'Slovo a mluvní takt v anglickém verši', Sborník Vysoké školy pedagogické v Olomouci. Jazyk a literatura (4): 55-79.

- (1958) 'Divadelní prostor a čas v dramatech Williama Shakespeara a Bena Jonsona', in Artur

Závodský (ed.) Franku Wollmannovi k sedmdesátinám. Sborník prací. Praha: Státní pedagogické nakladatelství, 648-656.

(1959) 'Rhythmical Ambivalence in the Poetry of T. S. Eliot', Anglia (77): 54-64.

(1961a) 'The Development of Rhyme-Scheme and of Syntactic Pattern in the English Renaissance

Sonnet', Acta Universitatis Palackianae Olomucensis - Philologica (4): 167-185.

(1961b) 'On the Relations of Language and Stanza Pattern in the English Sonnet', Worte und Werte, 214-231.

(1961c) 'Poezie Williama Butlera Yeatse', in William Butler Yeats, Slova snad pro hudbu, přel. Jiří Valja, Praha: SNKLU, 7-16.

(1964a) 'O překládání shakespearovského verše a prózy’, in William Shakespeare, Historie II Básnè, Praha: SNKLU, 682-717.

(1964b) 'William Blake', in William Blake, Svět v zrnku písku, Praha: Mladá fronta, přel. Jiří Valja, $129-149$.

(1964c) ‘Dramatická parodie Johna Gaye’, in John Gay, Žebrácká opera. Polly, přel. Jiří Valja, Praha: SNKLU, 7-18.

(1964d) 'Wildův Obraz Doriana Graye', in Oscar Wilde, Obraz Doriana Graye, přel. J. Z. Novák, Praha: Mladá fronta, 249-257.

(1964e) 'Literární díla přežívají..., in William Shakespeare, Romeo a Julie, přel. Zdeněk Urbánek, Praha: SNKLU, 131-133.

Některé významné práce v angličtině jsou přetištěny v knižním souboru Paralipomena (1971) a v českém překladu v knize Bude literární věda exaktní vědou? (1971, cf. Levý 1952, 1959) a dostupné online.

\section{Bibliografie dosud zjištěných překladů poezie Jiř́iho Levého řazená chronologicky}

Spender, Stephen (1947) ‘Ultima Ratio Regum' (Ultima Ratio Regum), Svobodné noviny 3(13, 16. 1.): 1. De la Mare, Walter (1947) 'Klícka' (The Cage), Svobodné noviny 3(47, 25. 2.): 1.

Yeats, William Butler (1947) 'U zahrad na stráni' (Down by the Salley Gardens), Svobodné noviny 3(118, 21. 5.): 1.

MacNeice, Louis (1947) 'Didymus' (Didymus), Svobodné noviny 3(171, 24. 7.): 1.

Hopkins, Gerard Manly (1948) 'Vyznání jeptišky' (A Nun Takes the Veil), Svobodné noviny 4(46, 24. 2.): 1948, 1.

Anonymous (1949) 'Dny. Arabská lidová píseň’ (Days. ? An Arabian Folk Song.), Kvart (5): 163.

Bišnu Dej ${ }^{8}$ (1949a) 'Srpek měsíce’ (The Crescent ?), Kvart (svazek 5): 146.

Bišnu Dej (1949b) 'V Moffusilu’ [sic] (In Mofussil ?), Kvart (svazek 5): 187.

Silva, José Asuncion9 (1949) 'Nokturno' (Nocturno III. “Una noche...”), Kvart (svazek 5): 318-319.

MacDiarmid, Hugh (1951) 'Duha' (The Watergaw), Časopis pro moderni filologii 34(4): 151-155.

Parra del Riego, Juan ${ }^{10}$ (1957) 'Serenáda Zuraj Zuritě (Serenata de Zuray Zurita. “Tiene parpados de luna..."), Host do domu 4(3): 350-351.

8 Bishnu Dey, 1909-1982, India.

9 José Asuncion Silva, 1865-1896, Colombia.

10 Juan Parra del Riego, 1894-1925, Peru - Uruguay. 
Tristan Tzara (1967) ‘Svítání v Řecku’ (Sur une aurore grecque. “voici le sable voici mon corps...”), Host do domu 14(3): 36-37.

\section{Použitá literatura}

Červenka, Miroslav (1967) 'Za Jiřím Levým', Česká literatura 15(2): 159-162.

Červenka, Miroslav (1971) 'Bibliografická poznámka', in Jiří Levý, Bude literární věda exaktní vědou?, Praha: Československý spisovatel, 457-459.

Jeřábek, Dušan (1967) 'Za Jiřím Levým', Časopis pro moderní filologii 49(3): 169-170.

Levý, Jiř́ (1957) České theorie prekladu, Praha: SNKLHU. ${ }^{11}$

(1963) Umění překladu, Praha: Československý spisovatel 1963.12

(ed.) (1966a) Západní literární věda a estetika, Praha: Československý spisovatel.

(1966b) ‘Československý strukturalismus a zahraniční kontext', in Milan Jankovič (ed.) Struktura a smysl literárního díla, Praha: Československý spisovatel, 58-69.

(1969) Die literarische Übersetzung: Theorie einer Kunstgattung, Frankfurt a. M. - Bonn:

Athenäum-Verlag.

- (1971a) Bude literární věda exaktní vědou?, Praha: Československý spisovatel, 1971.

(1971b) Paralipomena, Brno: UJEP.

(2011) The Art of Translation, Amsterdam - Philadelphia: John Benjamins Publishing Company.

MacDiarmid, Hugh and Michael Grieve, Alexander Scott (eds.) (1977) Hugh MacDiarmid Anthology, London: Routledge and Kegan Paul.

Macura, Vladimír (1999) 'Jiří Levý', in Slovník českých spisovatelů od roku 1945, Praha: Brána, 492-493.13 Shakespeare, William (1959-1964) Komedie I. - Historie II - Básnè, 6 sv. Praha: SNKLU.

Theimerová, Věra (1967) 'Soupis odborných prací Jiřího Levého', Česká literatura 15(3): 274-283. Rovněž: www.phil.muni.cz/angl/levy/levy_bibtheimer.rtf (access: 24. 4. 2018).

Yeats, William Butler (1961) Slova snad pro hudbu. Přel. Jiří Valja. Praha: SNKLU.

Yeats, William Butler and Edward Larissy (ed.) (2001) The Major Works, Oxford: Oxford University Press, 11.

\section{RESUMÉ}

Les activités de Jiř́ Levý, connu surtout en tant que théoricien de la traduction littéraire, sont réparties en plusieurs domaines de recherche : études sur la versification, théâtrologie, ainsi que histoire et théorie littéraires, sans oublier ses comptes rendus critiques de nombreuses publications étrangères. Les résultats de ses recherches sont présentés dans plusieurs études translatologiques. Le présent article comporte une appréciation de ses études anglaises et anglo-américaines les plus importantes, y compris plusieurs aspects de la poésie de T. S. Eliot et ses essais sur la Rennaissance en Angleterre, les drames de Shakespeare et Johnson et l'évolution du sonnet anglais. Dans ses études, Levý analyse le procédé par lequel les éléments constitutifs des langues influent sur les différentes formes de vers. Il développe la méthodologie des formalistes russes et des structuralistes tchèques, refutés à cette époque-là par la critique marxiste. A la suite de ces analyses, Levý définit certaines interactions compliquées des structures des langues, des schémas des rimes, des relations syntaxiques et des idées dans l'évolution du sonnet. Les découvertes acquises au cours de cette recherche sont inclues dans les chapitres concernant le rythme et la rime présentées dans son œuvre principale Umění překladu (L'Art de la traduction, 1963) où Levý a formulé des conclusions permettant de rapprocher les résultats de l'analyse textuelle avec lévolution historique : les différences entre la disposition des rimes en anglais et en italien par lesquelles l'auteur explique pourquoi

11 2. vydání: (1996) Praha: Ivo Železný.

12 2. revidované vydání (1983) Praha: Panorama, 3. vydání (1998) Praha: Ivo Železný, 4. vydání (2012) Praha: Apostrof.

13 Dostupné také online in Slovník české literatury po roce 1945 (2006) Praha: Ústav pro českou literaturu Akademie věd České republiky, http://www.slovnikceskeliteratury.cz/showContent.jsp?docId=420 (access: 24. 4. 2018). 
le sonnet de Petrarca selon le schéma $a b b a a b b a c d c c d c$ a été introduit dans la littérature anglaise sous forme simplifiée de Shakespeare $a b a b c d c d$ efef $g g$.

Concernant la littérature américaine, Levý a publié quelques études sur Walt Whitman. Dans le cadre de ses études translatologiques, il a mentionné plusieurs auteurs dont les œuvres sont traduites en tchèque. Il a publié d'autre part ses traductions tchèques de la poésie en langues étrangères; ces poèmes ne sont pas encore complètement rassemblés et analysés. Notre texte en comporte deux, suivis de la bibliographie de ces traductions, repérées jusquà nos jours.

prof. PhDr. Bohuslav Mánek, CSc.

Katedra anglického jazyka a literatury, Pedagogická fakulta, Univerzita Hradec Králové

bohuslav.manek@uhk.cz 